\title{
Identification and characterization of a new potyvirus infecting Muscari in Hungary
}

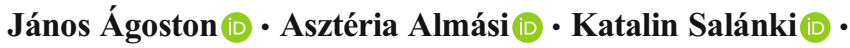 \\ László Palkovics
}

Accepted: 2 December 2020 / Published online: 11 December 2020

(C) The Author(s) 2020

\begin{abstract}
Grape hyacinths (Muscari spp.) are popular spring flowering bulbs in Europe and also in Hungary. In the spring of 2017, we came across grape hyacinth plants showing mosaic symptoms, which indicated viral infection. Currently Hyacinth mosaic virus (genus Potyvirus), a proposed member of the genus named Muscari mosaic virus, Arabis mosaic virus (genus Nepovirus), Cucumber mosaic virus (genus Cucumovirus) and Tobacco rattle virus (genus Tobravirus) are known to infect grape hyacinth. Leaf samples of symptomatic grape hyacinths were observed, collected and the presence of potyviruses was proved with potyvirus specific monoclonal antibody by ELISA and by potyvirus specific RT-PCR. Laboratory host plants and seed grown Muscari plants were inoculated with leaf sap and symptoms were recorded. Nucleotide sequences of the cloned fragments were compared to GenBank data. In the case of Muscari 'Helena' the highest nucleotide identity in the coat protein coding region was found with two Muscari mosaic virus iso-
\end{abstract}

J. Ágoston · L. Palkovics $(\bowtie)$

Department of Plant Pathology, Faculty of Horticultural Science, Szent István University, Budapest, Hungary

e-mail: palkovics.laszlo@szie.hu

J. Ágoston

Department of Agriculture, Faculty of Horticulture and Rural Development, John von Neumann University, Kecskemét, Hungary

\section{A. Almási · K. Salánki}

Plant Protection Institute, Centre for Agricultural Research, Budapest, Hungary lates (95.51\% and 95.79\%). In the case of the clones derived from Muscari 'Pink Sunrise' plant, the highest identity was recorded with Muscari mosaic virus isolates $(57.65 \%$ and $57.80 \%)$ and with a Tulip breaking virus strain $(55.13 \%)$ indicating the existence of a novel potyvirus species, tentatively named Muscari chlorotic mottle virus. The coat protein sequences were aligned and Maximum Likelihood trees were built to analyze phylogenetic relationships.

Keywords Muscari mosaic virus · Muscari chlorotic mottle virus · Potyvirus · ELISA $\cdot$ Hungary

Grape hyacinths (Muscari) are popular spring flowering bulbs in Europe, including Hungary. Currently the Royal General Bulb Growers' Association (KAVB)'s ornamental plant database contains 25 species and 94 cultivars (Koninklijke Algemeene Vereeniging voor Bloembollencultuur (KAVB) 2020). Its popularity is attributed to its ability to perennialize, fast vegetative propagation (Bryan 2002; Jelitto et al. 1995), relative cheapness, and they are undemanding. Four native species of grape hyacinth are recorded in Hungary: Muscari botryoides, M. racemosum (syn. M. neglectum), M. tenuifolium and M. comosum. Muscari armeniacum is not native but it and its cultivars are widely grown, they sometimes escape from gardens but are not invasive (Simon 2000).

Arabis mosaic virus (Bellardi and Pisi 1989; Samuitienè et al. 2008; Sastry et al. 2019), Cucumber mosaic virus (Navalinskienè and Samuitienè 2001; 
Samuitienè and Navalinskiené 2008; Sastry et al. 2019), Tobacco rattle virus (Navalinskienè and Samuitienè 2001; Sastry et al. 2019) have been reported from grape hyacinths. Potyviruses are also known to infect spring flowering bulbous plants. Currently Hyacinth mosaic virus is known as the only recognized potyvirus species capable of infecting Muscari (Alexandre et al. 2017; de Best et al. 2000; Derks and Vink-van den Abeele 1980; Pham et al. 2011; Sastry et al. 2019). Symptoms include light or dark green stripes and flecks on the foliage. Cultivars may show symptoms briefly in the growing season (de Best et al. 2000). Muscari mosaic virus (MuMV) is a proposed member of the genus Potyvirus that has not yet been approved as a species by the ICTV was also reported infecting Muscari in Latvia, the Netherlands and in Taiwan (Chiang and Chen 2011; Navalinskienè and Samuitienè 2001, 2006; Pham et al. 2011; Sastry et al. 2019). Nucleotide sequence data of the coat protein is available from the Netherlands and Taiwan (Acc. No.: EU042752; Acc. No.: HQ400612) and they have $98.93 \%$ identity.

In the spring of 2017, we came across grape hyacinths showing mosaic symptoms in a nursery in Nyársapát, Central Hungary (GPS reference N47.087373, E19.780381), where symptomatic leaf samples of Muscari cultivars 'Helena' and 'Pink Sunrise' were collected on March 28, 2018. Samples were transported dry, on ice and stored at $-70{ }^{\circ} \mathrm{C}$ until further processing.

Symptom development was observed in 2017, 2018, 2019 and 2020 under open field conditions and in a vector free greenhouse. In both populations the disease occurrence was $100 \%$, symptoms were most visible in early spring at bud emergence, and became masked with warm weather and after flowering. Symptoms on the abaxial surface of the leaves were more prominent, as the adaxial side has a waxy layer.

Helena cultivar had light green or greenish yellow 2$3 \mathrm{~mm}$ wide bands mainly in the middle part of the lamina in the entire length of the leaves (Fig. 1a). These bands become wider as bud development and flowering proceeded. After flowering the bands faded.

In the case of Pink Sunrise cultivar, the symptoms were different (Fig. 1b). Leaves had a general yellowgreen appearance, the mosaic was mottle-like, 0.2$1 \mathrm{~mm}$ wide yellow to yellow green stripes, occasionally dark green. The stripes were also visible on the leaf margin and more prominent near the veins. As flowering progressed markings became masked, but
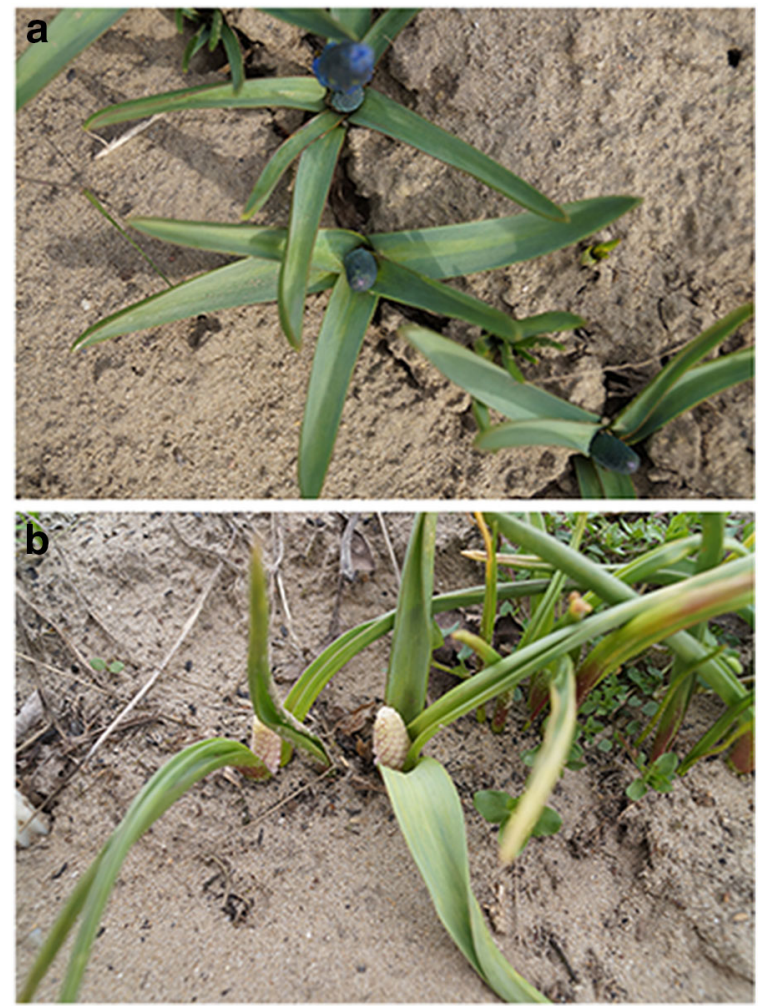

Fig. 1 a Muscari 'Helena' and b Muscari 'Pink Sunrise' plants grown under open field conditions

the general yellower appearance persisted. Interestingly, in 2019 after a 5-day cold spell in May symptoms reappeared on the foliage, and disappeared when temperature increased. In the case of the infected plants no symptoms appeared on the petals, and plants set seed. Compared to $M$. armeniacum the seed set and general vigor of the plants were decreased, wilting occurred 7 to 10 days earlier each year.

Laboratory test plants Chenopodium murale, Nicotiana benthamiana and N. tabacum 'Xanthi' were sap inoculated and maintained for 6 weeks after inoculation to observe symptoms. During the 6 -week period no symptoms were observed on laboratory host plants, which indicated potyvirus infection. Muscari armeniacum seedlings were also sap inoculated to fulfill Koch's postulates. The inoculated plants did not show symptoms in the first vegetative season, which is in accordance with former observations on other spring flowering bulbous plants (de Best et al. 2000; Dekker et al. 1993; Valverde et al. 2012). Since the dormancy period of M. armeniacum is short, bulbs in moist soils and substrates re-grow in August under Hungarian 
climatic conditions. The freshly grown leaves showed mosaic symptoms in both cases (data not shown).

ELISA tests were carried out in duplicates on samples based on potyvirus specific MAb PTY1 (Jordan and Hammond 1991) antibody supplied by Agdia according to the instructions provided. For negative controls Ch. murale seedlings grown in a vector free greenhouse were used, positive controls were provided by the supplier in the kit. Absorbance values of the negative controls were 0.034 and 0.047 ; of $M$. 'Helena' samples 1.594 and 1.647 and of $M$. 'Pink Sunrise' samples 1.713 and 1.751. These results indicated potyvirus infection in both cases.

To identify the potyvirus species total RNA extraction was carried out by the method described by White and Kaper (1989). First strand cDNA was synthetized with RevertAid First Strand cDNA Synthesis Kit (ThermoScientific), with poly $\mathrm{T}_{2}$ reverse primer $\left(5^{\prime}\right.$ CGGGGATCCTCGAGAAGCTTTTTTTTTTTTTTTTT $-3^{\prime}$ ) described by Salamon and Palkovics (2005). For the amplification of the $\mathrm{C}$ terminus of the $\mathrm{NIb}$, the complete coat protein, the complete 3'UTR region and part of the polyA tail universal potyvirus forward primer poty7941 (5'GGAATTCCCGCGGNAAYAAYAGYGGNCARC C $3^{\prime}$ ) and poly $T_{2}$ were used (Salamon and Palkovics 2005). PCR products about 1600 bp length were excised and purified with High Pure PCR Product Purification Kit (ROCHE) then ligated into pGEM®-T Easy vector (Promega). The nucleotide sequences were determined and deposited in the GenBank (Muscari 'Helena' Acc. No.: MK642311, Muscari 'Pink Sunrise' Acc. No.: MK642312). To verify whether a single potyvirus species is present in the infected Muscari plants, the original PCR products were digested with restriction enzymes present in the determined sequences (Acc. No.: MK642311: EcoRV; Acc. No.: MK642312: HpaI). In both cases the PCR products were completely digested and resulted exclusively the two predicted restriction fragments, indicating the presence of a single potyvirus species in the infected plants, respectively.

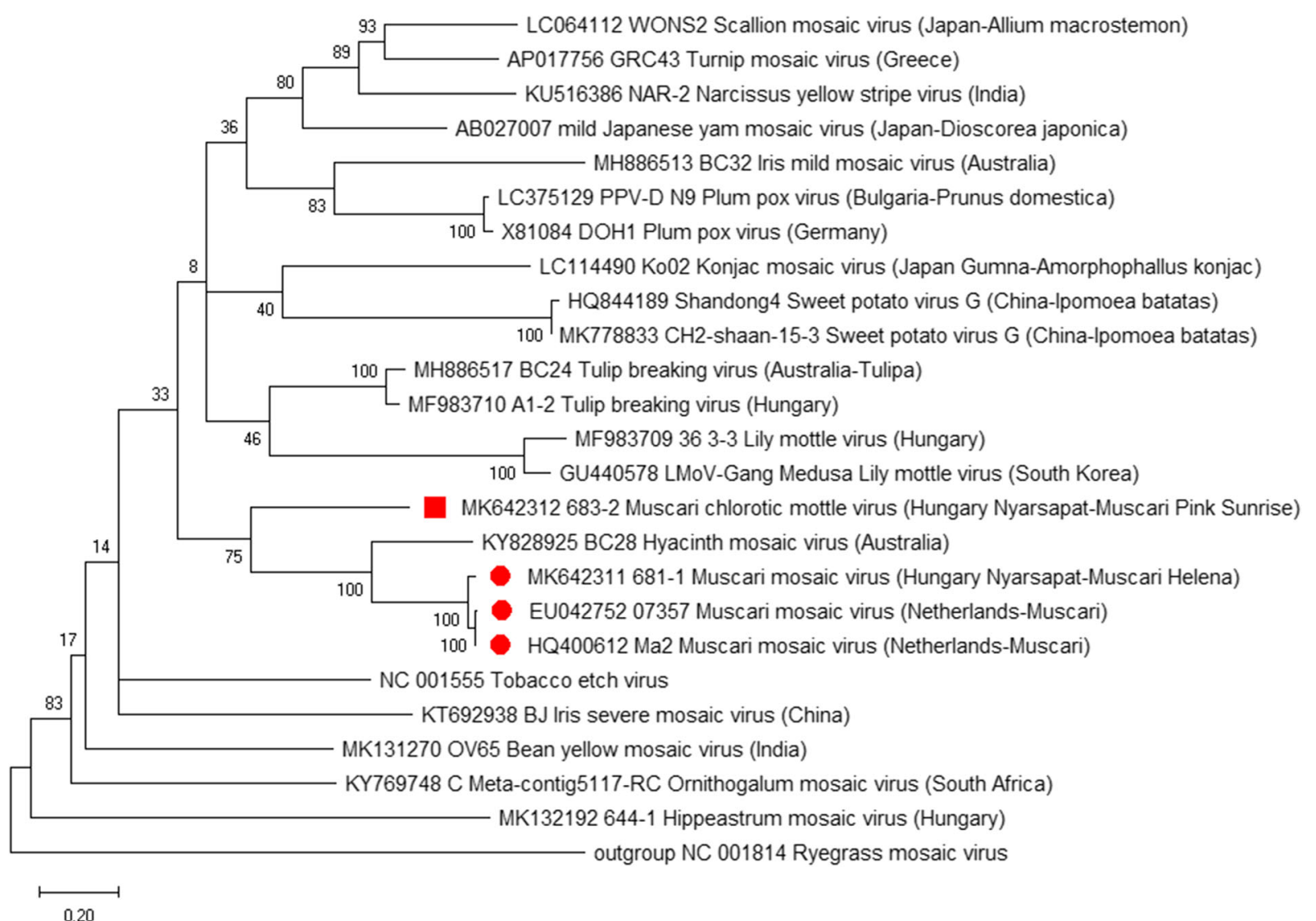

Fig. 2 Maximum Likelihood phylogenetic tree built from the nucleotide sequences of the complete CP regions of Muscari mosaic virus and Muscari chlorotic mottle virus isolates and potyvirus isolates retrieved from the GenBank 
Each nucleotide sequence was compared to available sequences in the GenBank using megaBLAST module (Morgulis et al. 2008) and the nucleotide sequences were uploaded to GenBank.

The full coat protein region acquired from cultivar Helena had 95.895\% nucleotide identity with Acc. No.: EU042752 and 96.019\% with Acc. No.: HQ400612, while it had $95.895 \%$ amino acid (aa) identity with both isolates, which are isolates of Muscari mosaic virus, a proposed member of the genus Potyvirus. The sequence of the Hungarian isolate shared $60.523 \% \mathrm{nt}$ and $63.805 \%$ aa identity with the most closely-related accepted potyvirus species, Japanese yam mosaic virus Acc. No. AB027007. Nucleotide analyses demonstrated that $\mathrm{cv}$. Helena was infected with an isolate belonging to the tentative potyvirus species Muscari mosaic virus.

According to the BLAST results the complete coat protein region derived from $M$. 'Pink Sunrise' had the highest nt identity with the previously analyzed Muscari mosaic virus isolate, of only $66.169 \%$ nt $(65.298 \%$ aa) (Acc. No.: MK642311) and with the two other Muscari mosaic virus isolates $66.044 \% \mathrm{nt}(64.925 \%$ aa) and $65.769 \%$ nt $(65.298 \%$ aa) (Acc. No.: EU042752 and HQ400612), respectively. For the complete coat protein region, the highest nt identity among accepted potyvirus species was found with a Tulip breaking virus strain (Acc. No.: MH886517), 63.692\% (64.419\% aa). Interestingly, for the $440 \mathrm{nt}$ long carboxy-terminal region of the CP the highest identity was $76 \%$ with Plum pox virus $D$ serotypes, but for the complete $\mathrm{CP}$ region it was just $61.192 \%$ (59.854\% aa). According to the 10th ICTV Report on Virus Taxonomy species demarcation criteria require less than $76 \%$ nt identity and less than $82 \%$ aa identity in the polyprotein or coat protein region in the case of different potyvirus species (Wylie et al. 2017). Based on these results a new potyvirus species was identified in grape hyacinth tentatively named Muscari chlorotic mottle virus.

For phylogenetic analyses MEGA X was program was used (Kumar et al. 2018). ClustalW (Larkin et al. 2007) alignments were built from the nucleotide and amino acid sequences of the complete $\mathrm{CP}$ regions of the potyviruses with the highest similarity according to the BLAST results. The following accessions were included: Bean yellow mosaic virus (MK131270), Hippeastrum mosaic virus (MK132192), Hyacinth mosaic virus (KY828925), Iris mild mosaic virus (MH886513), Iris severe mosaic virus (KT692938),

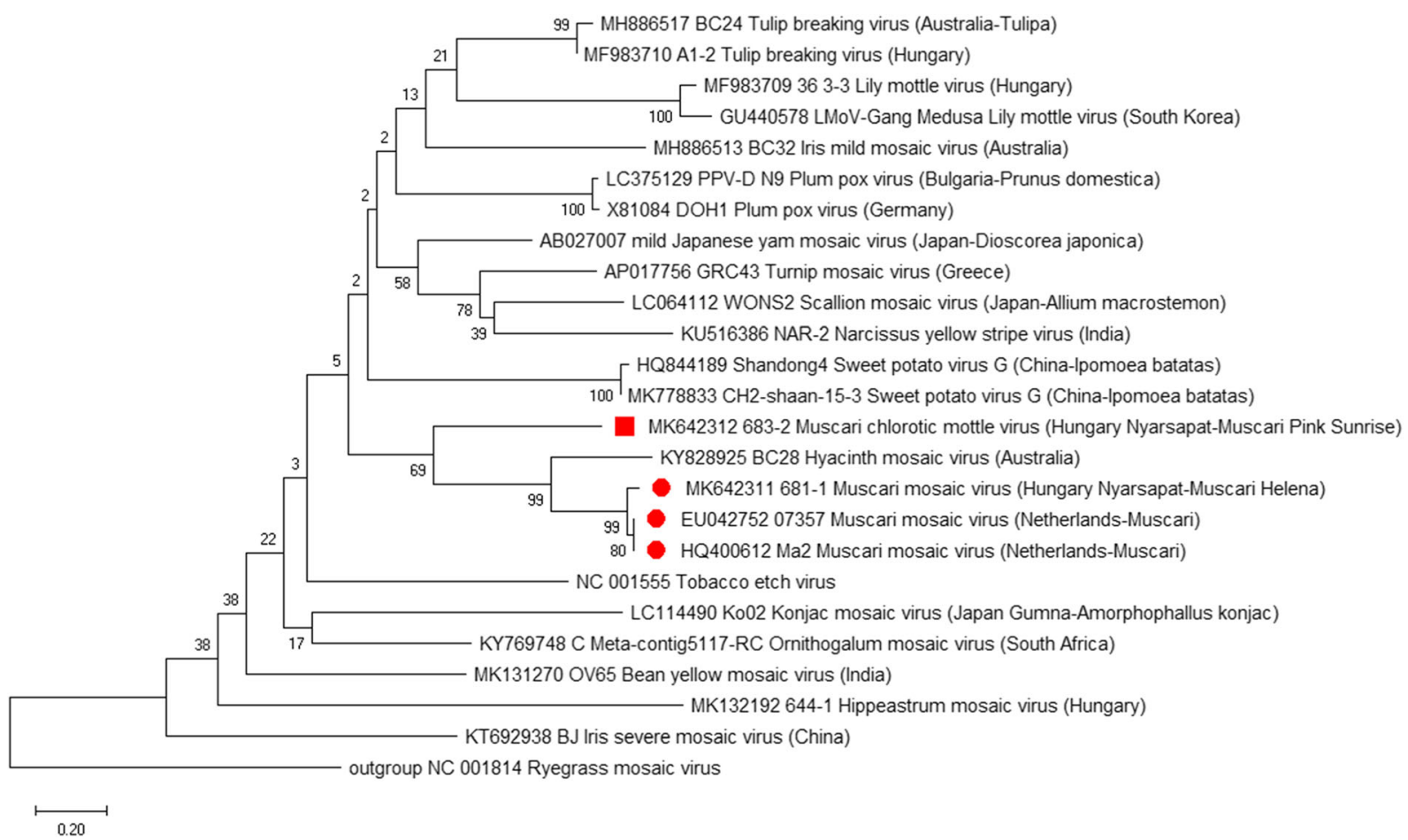

Fig. 3 Maximum Likelihood phylogenetic tree built from the amino acid sequences of the complete CP regions of Muscari mosaic virus and Muscari chlorotic mottle virus isolates and potyvirus isolates retrieved from the GenBank 
Japanese yam mosaic virus (AB027007), Konjac mosaic virus (LC114490), Lily mottle virus (MF983709, GU440578), Muscari chlorotic mottle virus (MK642312), Muscari mosaic virus (EU042752, HQ400612, MK642311), Narcissus yellow stripe virus (KU516386), Ornithogalum mosaic virus (KY769748), Plum pox virus (LC375129, X81084), Scallion mosaic virus (LC064112), Sweet potato virus G (HQ844189, MK778833), Tobacco etch virus (NC_001555), Tulip breaking virus (MH886517, MF983710), Turnip mosaic virus (AP017756) and Ryegrass mosaic virus (NC_001814) as outgroup. The best fit DNA model with the lowest corrected Akaike Information Criterion (AIC) value was used (Nei and Kumar 2000) to construct a Maximum Likelihood (ML) tree (Felsenstein 1981; Guindon and Gascuel 2003) for CP nt and aa sequences. The reliability of the trees were tested with the Bootstrap method (Felsenstein 1985) with 1000 replications. For the nt Time Reversible model (Tavaré 1986) with Gamma distribution and invariant sites was used, for aa LG model (Le and Gascuel 2008) was used with gamma distribution to build Maximum Likelihood trees. The phylogenetic analysis has shown that the two virus isolates from Muscari species form separate monophyletic groups. (Figs. 2 and 3). In both trees hyacinth mosaic virus, muscari mosaic virus and muscari chlorotic mottle virus are forming a distinct clade, which means they had a common ancestor. Hyacinth mosaic virus and muscari mosaic virus are more closely related to each other than muscari chlorotic mottle virus, which is supported by high Bootstrap values (99-100\%).

In the present survey symptomatic Muscari cultivars were tested from Hungary. To fulfill Koch's postulates seed grown M. armeniacum plants were inoculated and symptoms were observed in the next vegetative period, which is in accordance with earlier findings in spring flowering bulbous plants (de Best et al. 2000; Dekker et al. 1993; Valverde et al. 2012).

This is the first report of successful detection of Muscari chlorotic mottle virus by MAb PTY1 antibody. The fulfillment of Koch's postulates, positive ELISA tests, the determination of the complete coat protein sequences and the phylogenetic analyses clearly demonstrate that this potyvirus is a novel species, and distinct from other potyviruses. This is the first time that Muscari mosaic virus has been detected and reported from Hungary, and it is one out of only three MuMV sequences deposited in GenBank.
Our results show, that beside Hyacinth mosaic virus two other candidate members of the genus Potyvirus can infect and cause mosaic symptoms on grape hyacinth plants (Chiang and Chen 2011; Navalinskienè and Samuitienè 2001, 2006; Pham et al. 2011). Since the primary hosts for all potyviruses are supposed to be monocotyledonous bulbs and grasses (Ohshima 2012) the further analysis of these viruses may result in the better understanding of the evolution of potyviruses.

Supplementary Information The online version contains supplementary material available at https://doi.org/10.1007/s10658020-02182-8.

Acknowledgements Our research was supported by grants EFOP-3.6.1-16-2016-00006 "The development and enhancement of the research potential at John von Neumann University" awarded by the Hungarian Government and co-financed by the European Social Fund, and Higher Education Institutional Excellence Program, NKFIH-1159-6/2019 grant by the Ministry for Innovation and Technology.

Availability of data and material All relevant data are within the paper and its Supporting Information files.

Authors' contributions All authors contributed equally to this work.

Funding Open Access funding provided by Szent István University.

\section{Compliance with ethical standards}

This article has not been submitted elsewhere for publication.

This article does not contain any studies with human participants or animals performed by any of the authors.

Informed consent was obtained from all individual participants included in the study.

Conflict of interest The authors declare that there is no conflict of interest.

Open Access This article is licensed under a Creative Commons Attribution 4.0 International License, which permits use, sharing, adaptation, distribution and reproduction in any medium or format, as long as you give appropriate credit to the original author(s) and the source, provide a link to the Creative Commons licence, and indicate if changes were made. The images or other third party material in this article are included in the article's Creative Commons licence, unless indicated otherwise in a credit line to the material. If material is not included in the article's Creative Commons licence and your intended use is not permitted by statutory regulation or exceeds the permitted use, you will need to obtain 
permission directly from the copyright holder. To view a copy of this licence, visit http://creativecommons.org/licenses/by/4.0/.

\section{References}

Alexandre, M. A. V., Duarte, L. M. L., Rodrigues, L. K., Ramos, A. F., \& Harakava, R. (2017). Hyacinth mosaic virus infecting Hyacinthus sp. plants in Brazil. Tropical Plant Pathology, 42(1), 51-54. https://doi.org/10.1007/s40858-016-0121-5.

Bellardi, M. G., \& Pisi, A. (1989). Virosi del giacinto e del muscari. Colture Protette, 18, 101-104.

Bryan, J. E. (2002). Bulbs (Rev. ed.). Portland: Timber Press.

Chiang, F. L., \& Chen, C. C. (2011). Identification of a grape hyacinth-infecting virus and the production of its serological and molecular detection tools. Plant Protection Bulletin (Taipei), 53(3), 69-81.

de Best, A. L. I. C., Zwart, M. J., van Aartrijk, J., van den Ende, J. E., \& Peeters, J. M. M. (2000). Ziekten en afwijkingen bij bolgewassen: Liliaceae (Vols. 1-2, Vol. 1). Lisse: Laboratorium voor Bloembollenonderzoek.

Dekker, E. L., Derks, A. F. L. M., Asjes, C. J., Lemmers, M. E. C., Bol, J. F., \& Langeveld, S. A. (1993). Characterization of potyviruses from tulip and lily which cause flower-breaking. Journal of General Virology, 74, 881-887. https://doi. org/10.1099/0022-1317-74-5-881.

Derks, A. F. L. M., \& Vink-van den Abeele, J. L. (1980). Hyacinth mosaic virus: symptoms in hyacinths, serological detection, and relationships with other potyviruses. In Acta Horticulturae (Vol. 109, pp. 495-502). Presented at the III International Symposium on Flower Bulbs, Nyborg, Denmark: International Society for Horticultural Science (ISHS), Leuven, Belgium. https://doi. org/10.17660/ActaHortic.1980.109.74.

Felsenstein, J. (1981). Evolutionary trees from DNA sequences: A maximum likelihood approach. Journal of Molecular Evolution, 17(6), 368-376. https://doi.org/10.1007 /BF01734359.

Felsenstein, J. (1985). Confidence limits on phylogenies: An approach using the bootstrap. Evolution, 39(4), 783-791. https://doi.org/10.1111/j.1558-5646.1985.tb00420.x.

Guindon, S., \& Gascuel, O. (2003). A simple, fast, and accurate algorithm to estimate large phylogenies by maximum likelihood. Systematic Biology, 52(5), 696-704. https://doi. org/10.1080/10635150390235520.

Jelitto, L., Schacht, W., Epp, M. E., Baumgardt, J. P., \& Fessler, A. (1995). Hardy herbaceous perennials. Portland: Timber Press.

Jordan, R., \& Hammond, J. (1991). Comparison and differentiation of potyvirus isolates and identification of strain-, virus-, subgroup-specific and potyvirus group-common epitopes using monoclonal antibodies. Journal of General Virology, 72(1), 25-36. https://doi.org/10.1099/0022-1317-72-1-25.

Koninklijke Algemeene Vereeniging voor Bloembollencultuur (KAVB). (2020). Ornamental Plant Database. Hillegom: Koninklijke Algemeene Vereeniging voor Bloembollencultuur (KAVB). https://www.kavb. nl/siergewassen. Accessed 29 December 2019.
Kumar, S., Stecher, G., Li, M., Knyaz, C., \& Tamura, K. (2018). MEGA X: Molecular evolutionary genetics analysis across computing platforms. Molecular Biology and Evolution, 35(6), 1547-1549. https://doi.org/10.1093/molbev/msy096.

Larkin, M. A., Blackshields, G., Brown, N. P., Chenna, R., McGettigan, P. A., McWilliam, H., Valentin, F., Wallace, I. M., Wilm, A., Lopez, R., Thompson, J. D., Gibson, T. J., \& Higgins, D. G. (2007). Clustal W and Clustal X version 2.0. Bioinformatics, 23(21), 2947-2948. https://doi.org/10.1093 /bioinformatics/btm404.

Le, S. Q., \& Gascuel, O. (2008). An improved general amino acid replacement matrix. Molecular Biology and Evolution, 25(7), 1307-1320. https://doi.org/10.1093/molbev/msn067.

Morgulis, A., Coulouris, G., Raytselis, Y., Madden, T. L., Agarwala, R., \& Schäffer, A. A. (2008). Database indexing for production MegaBLAST searches. Bioinformatics, 24(16), 1757-1764. https://doi.org/10.1093/bioinformatics/btn322.

Navalinskiene, M., \& Samuitienè, M. (2001). Viruses affecting some bulb and corm flower crops. Biologija, 4, 40-42.

Navalinskienè, M., \& Samuitienè, M. (2006). Dekoratyviniu augalu virusinés ligos ir ju sukèlëjai Lietuvoje. Kaunas: Lututè.

Nei, M., \& Kumar, S. (2000). Molecular evolution and phylogenetics. In Oxford. New York: Oxford University Press.

Ohshima, K. (2012). Plant potyvirus evolution: The survey of the genetic structure of populations. Uirusu, 62(2), 151-160. https://doi.org/10.2222/jsv.62.151.

Pham, K. T. K., de Kock, M. J. D., Lemmers, M. E. C., \& Derks, A. F. L. M. (2011). Molecular identification of potyviruses infecting bulbous ornamentals by the analysis of coat protein (cp) sequences. In Acta Horticulturae (Vol. 901, pp. 167172). Presented at the XII International Symposium on Virus Diseases of Ornamental Plants, Haarlem, Netherlands: International Society for Horticultural Science (ISHS), Leuven, Belgium. https://doi.org/10.17660 /ActaHortic.2011.901.21.

Salamon, P., \& Palkovics, L. (2005). Occurrence of Colombian datura virus in Brugmansia hybrids, Physalis peruviana L. and Solanum muricatum Ait. in Hungary. Acta Virologica, 49(2), 117-122.

Samuitienė, M., \& Navalinskiene, M. (2008). Occurrence of Cucumber mosaic cucumovirus on ornamental plants in Lithuania. Zemdirbyste-Agriculture, 95(3), 135-143.

Samuitienè, M., Navalinskienè, M., \& Jackevičienė, E. (2008). Arabis mosaic virus on ornamental plants. Biologija, 54(4), 264-268. https://doi.org/10.2478/v10054-008-0054-0.

Sastry, K. S., Mandal, B., Hammond, J., Scott, S. W., \& Briddon, R. W. (2019). Encyclopedia of plant viruses and Viroids. New Delhi: Springer India. https://doi.org/10.1007/978-81322-3912-3.

Simon, T. (2000). A magyarországi edényes flóra határozója: harasztok - virágos növények (4th ed.). Budapest: Nemzeti Tankönyvkiadó.

Tavaré, S. (1986). Some probabilistic and statistical problems in the analysis of DNA sequences. In Some Mathematical Questions in Biology: DNA Sequence Analysis (Vol. 17, pp. 57-86). Providence: American Mathematical Society. 
Valverde, R. A., Sabanadzovic, S., \& Hammond, J. (2012). Viruses that enhance the aesthetics of some ornamental plants: Beauty or beast? Plant Disease, 96(5), 600-611. https://doi.org/10.1094/PDIS-11-11-0928-FE.

White, J. L., \& Kaper, J. M. (1989). A simple method for detection of viral satellite RNAs in small plant tissue samples. Journal of Virological Methods, 23(2), 83-93. https://doi. org/10.1016/0166-0934(89)90122-5.
Wylie, S. J., Adams, M., Chalam, C., Kreuze, J., López-Moya, J. J., Ohshima, K., Praveen, S., Rabenstein, F., Stenger, D., Wang, A., Zerbini, F. M., \& ICTV Report Consortium. (2017). ICTV virus taxonomy profile: Potyviridae. Journal of General Virology, 98(3), 352-354. https://doi.org/10.1099 /jgv.0.000740. 